\title{
OPTIMAL TAX POLICY WHEN FIRMS ARE INTERNATIONALLY MOBILE
}

\author{
JOHANNES BECKER \\ Clemens FUEST
}

CESIFO WORKING PAPER NO. 1592

CATEGORY 1: PubliC FinANCE

NOVEMBER 2005

An electronic version of the paper may be downloaded

- from the SSRN website:

www.SSRN.com

- from the CESifo website:

www.CESifo-group.de 


\title{
OPTIMAL TAX POLICY WHEN FIRMS ARE INTERNATIONALLY MOBILE
}

\begin{abstract}
The standard tax theory result that investment should not be distorted is based on the assumption that profits are locally bound. In this paper we analyze the optimal tax policy when firms are internationally mobile. We show that the optimal policy response to increasing firm mobility may be taxation, subsidization or non-distortion of investment depending on whether the mobile firms are more or less profitable than the average firm in the economy. Our findings may contribute to understanding recent tax policy developments in many OECD countries.
\end{abstract}

JEL Code: H25, H21.

Keywords: corporate taxes, optimal tax policy.

\author{
Johannes Becker \\ University of Cologne \\ Department of Public Finance \\ Albertus-Magnus-Platz \\ 50923 Cologne \\ Germany \\ johannes.becker@uni-koeln.de
}

\author{
Clemens Fuest \\ University of Cologne \\ Department of Public Finance \\ Albertus-Magnus-Platz \\ 50923 Cologne \\ Germany \\ clemens.fuest@uni-koeln.de
}




\section{Introduction}

Standard optimal tax theory recommends that small open economies should not impose source-based taxes on the normal return to capital if capital is internationally mobile (Gordon (1986), Sinn (1990)). If capital is taxed at source, investment is distorted and national welfare declines. The literature has therefore proposed a whole class of investment-neutral tax systems in which (pure) profits can be taxed without distorting the investment decision. These proposals are often summarized under the label 'consumption tax systems'. The main characteristic of these investment-neutral corporate tax systems is that tax payments are zero if the project return merely equals the cost of capital. In technical terms, the present value of depreciation allowances (PVDA) is equal to $100 \%$ of the purchase price of the capital good.

In 1982, the unweighted average of the PVDA for an investment in plant and machinery across a large number of OECD countries $^{1}$ was $81 \%$, the PVDA for industrial buildings $48 \%$ (Devereux, Griffith \& Klemm (2002)) ${ }^{2}$. With the exception of Ireland, no country allowed for immediate depreciation or an equivalent in present value terms, i.e. a PVDA of $100 \%$. Since then, the opening of capital markets and increasing economic integration among these countries should have increased the cost of distorting investment. ${ }^{3}$ In sum, we should have expected countries to reform their tax system lowering the taxation of the normal return, i.e. increasing the PVDA.

But, empirical observations do not support the view that governments pursued this kind of tax policy strategy. Twenty-one years later, in 2003, the unweighted average of the PVDA has dropped to $75 \%$ for plant and machinery and to $33 \%$ for industrial buildings. This means that, on average, countries have taken the opposite direction of what standard optimal tax theory suggests.

\footnotetext{
${ }^{1}$ These countries are Australia, Austria, Belgium, Canada, Finland, France, Great Britain, Germany, Greece, Ireland, Italy, Japan, Netherlands, Norway, Portugal, Spain, Sweden, Switzerland and the USA.

${ }^{2}$ We adopted the calculations with a fixed real interest rate (10\%) and a fixed rate of inflation $(3,5 \%)$ in order to keep the numbers comparable across time and countries.

${ }^{3}$ Of course, source-based taxation is only one level of taxation. Taking into account intermediate-level and household taxation, it is unclear whether the normal return to capital is taxed or not, as Gordon, Kalambokidis, Rohaly \& Slemrod (2004) show for the US, and Becker \& Fuest (2005) for Germany.
} 
Using the Corporate Tax Data Base provided by the Institute for Fiscal Studies (IFS) and described and analyzed in Devereux, Griffith \& Klemm (2002), diagram 1 depicts each change in the statutory tax rates and the $\mathrm{PVDA}^{4}$ of the OECD countries enumerated in footnote 1 in the years 1982-2003. The $x$-axis measures changes of the tax rate, the $y$-axis the variation in the tax base. Data points which are not on the axes present a simultaneous change of the tax rate and the tax base. Thus, we get four quadrants among which two are (potentially) revenue-neutral, because the variation of one tax parameter is "financed" by the variation of the other one. In addition, as long as the tax system is on the increasing part of the Laffer curve, tax reforms in quadrant II are clearly revenue-decreasing and those in quadrant IV are revenue-increasing.

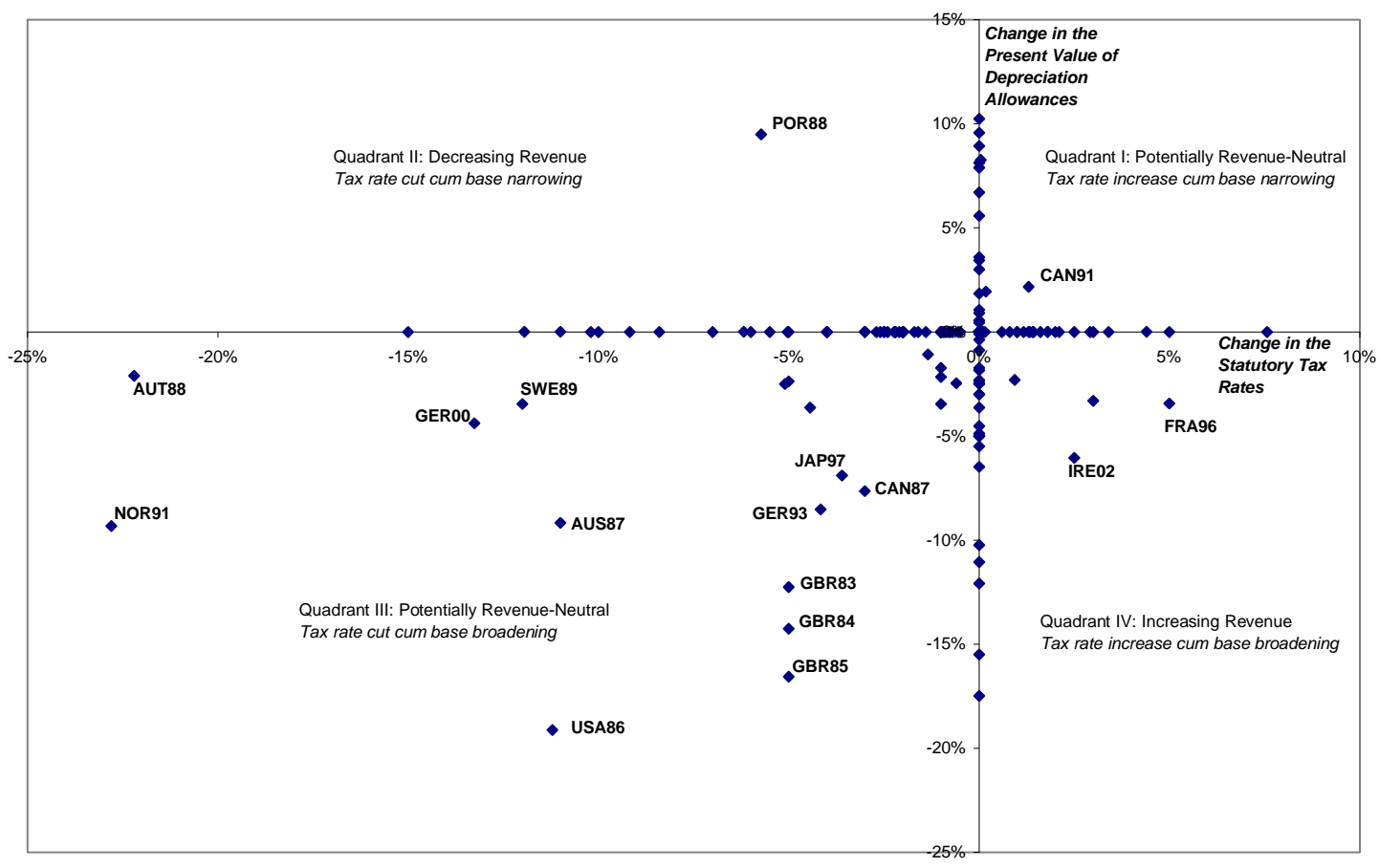

Diagram 1: Tax reforms in different OECD countries 1982-2003. Data source:

Devereux et al. (2002).

As the diagram shows, a great deal of tax policy reforms consists of a variation

\footnotetext{
${ }^{4}$ The change in the PVDA is calculated as an unweighted average of the changes in the PVDA of plant and machinery and the PVDA of industrial buildings.
} 
of either the tax rate or the tax base, i.e. the data points are located on the axes. Among the tax reforms which changed the tax rate and the tax base at the same time, only the Canadian tax reform of 1991 follows the way predicted by theory; however, it just reversed the reform of 1990 to the same extent and may therefore be interpreted as a mere correction. The only country ${ }^{5}$ to implement a revenue decreasing tax reform of both the tax rate and base is Portugal in 1988, whereas the United States (1992), Finland (1995), France (1996) and Ireland (2002) implement revenue increasing tax reforms (quadrant IV).

Most tax reforms which changed tax rate and base simultaneously were of the tax rate cut cum base broadening kind, which consists of lowering the statutory tax rates on business profits and reducing the present value of depreciation allowances at the same time. Among those are tax reforms in Great Britain, Germany and Japan, and - probably known best - the US tax reform of 1986. It is striking that even the large countries which could be expected to be relatively autonomous in their tax policy pursued this kind of strategy. The question arises how this development can be explained.

Compared to the literature on the efficiency and welfare enhancing effects of consumption tax systems, the literature explaining the obvious deviation from this ideal is relatively scarce. There are basically two approaches to explain this trend.

A first approach is based on the idea of 'policy learning', which is extensively discussed in the political science literature (see e.g. Steinmo (2003) and Swank \& Steinmo (2002)): Inspired by the fundamental reforms in Great Britain and the US, policymakers around the world followed their example and adjusted their tax system to the new model (e.g. see Whalley (1990) and Gordon (1992)). The underlying assumption is that policymakers do not have an explicit model of the economy in mind and no clear efficiency goals, but they do observe other policymakers and try to copy their strategies when they observe successful ones. ${ }^{6}$ The

\footnotetext{
${ }^{5}$ The recent tax policy reforms in the U.S. are not included in the diagram. As Gordon et al. (2004) show, these reforms narrowed the tax base by improving depreciation rules for investment goods, and should therefore be depicted in quadrant II. Combined with various opportunities of tax exempt savings and the continued deductability of interest payments, this policy ends up subsidizing the marginal investment.

${ }^{6}$ Another aspect here is that the US was an important supplier of foreign direct investment at the time. The foreign tax credit system enables the host country to increase tax rates on US multinationals up to the US statutory rate without increasing the effective tax rate for these
} 
US tax reform of 1986 was considered to be a success in historic dimensions and could have triggered similar reforms in other countries (see diagram 1).

The second approach is the attempt to explain tax rate cut cum base broadening policy as an optimal response to a changing economic environment. Haufler \& Schjelderup (2000) show that, if multinational firms earn supernormal profits and if they may shift these profits to low tax countries via transfer pricing, it is optimal to reduce tax rates and broaden tax bases, despite the distortion of investment caused by this policy. Fuest \& Hemmelgarn (2005) show that a tax rate cut cum base broadening policy may be optimal in the presence of income shifting through thin capitalization even if there are no pure profits. Another argument is provided by Bond (2000) who observes that "the increase in the importance of foreign direct investment flows over the last fifteen years or so has been accompanied by corporate tax reforms of this [tax rate cut cum base broadening] type. This coincidence does not establish any causal link from globalization to tax changes, but other explanations (...) appear to be scarce" (p. 173). He proposes to interpret the tax rate cut cum base broadening to be the optimal tax policy reaction to the existence of mobile and highly profitable firms. Without using a formal model, he suggests a setting in which multinational companies are assumed to be very sensitive to the effective average tax rate whereas investment by immobile firms is relatively insensitive to the effective marginal tax rate. Bond concludes that a government then might increase domestic investment by lowering the statutory tax rate and accepting a broader tax base, even though this results in a higher cost of capital.

In this paper, we contribute to the second approach to explain the trend towards low tax rates and broad tax bases. Surprisingly, the question of how optimal corporate tax policy looks like in the presence of internationally mobile firms, has not been investigated yet in a formal model. ${ }^{7}$ Of course, firm mobility as such has been extensively analyzed in the literature on foreign direct investment (Lipsey (2001)) and the new economic geography (see Ottaviano \& Thisse (2003)

firms. When the US lowered the tax rates fundamentally, other countries were forced to do the same if they did not want to push the US firms out of the country (Slemrod (2004)).

${ }^{7}$ As Devereux, Lockwood \& Redoano (2004) put it, existing models do not account for the fact that governments have two instruments, the tax rate and the tax base. Second, these models ignore other forms of mobility than capital mobility. 
for a survey). There are also several contributions analyzing intergovernmental competition in corporate tax rates with firm mobility (Boadway, Cuff \& Marceau (2002), Fuest (2005)). But, to the best of our knowledge, this contribution is the first to investigate the optimal structure of the corporate tax system in the presence of firm mobility in a formal model. We analyze this question in a general framework, where firms differ in profitability and mobility costs. The government may use the tax base and the tax rate as policy parameters. We show that the mobility of firms across borders does create incentives for governments to deviate systematically from investment neutrality. The optimal policy depends on how profitable mobile firms are, relative to immobile firms. If the marginal mobile firm is more profitable than the average firm in the country, a tax rate cut cum base broadening policy is optimal. The reason is that this policy redistributes the tax burden from mobile to immobile firms. Thus, mobile firms can be prevented from leaving the country without losing too much tax revenue. But if the marginal mobile firm is less profitable than the average firm in the economy, a tax rate cut cum base broadening policy reduces welfare. In this case, the optimal tax policy consists of subsidizing the normal return to capital and increasing the statutory tax rate.

The remainder of the paper is organized as follows: In section 2, we present a very simple two firm model which clarifies our argument and the intuition. Section 3 provides a more general model where we analyze a continuum of firms differing in profitability and mobility and refine the results derived in the previous section. In section 4 we discuss the implications of our results and conclude.

\section{Optimal tax policy in a two mobile firm setting}

Consider an economy with only two mobile profit-maximizing firms, which are owned by some domestic residents. Both firms differ in profitability. Profitability depends on firm-specific characteristics, called $A$, and location-specific characteristics, called $B$. Both firms invest in capital $\tilde{K}$, which is provided by a world

capital market, and receive income of $F\left(\tilde{K}_{i}, A_{i}, B_{i}\right)$ with $i=1,2$. The produc- 
tion technology $F$ is well-behaved $\left(F_{K K}<0<F_{K}\right)$. After-tax profits are:

$$
\pi_{i}=(1-u) F\left(\tilde{K}\left(A_{i}, B_{i}\right), A_{i}, B_{i}\right)-(1-u \alpha) \tilde{K}\left(A_{i}, B_{i}\right)
$$

where $u$ is the statutory tax rate and $\alpha$ the rate of tax depreciation allowances. ${ }^{8}$ Optimal investment implies

$$
\frac{\partial F\left(\tilde{K}\left(A_{i}, B_{i}\right), A_{i}, B_{i}\right)}{\partial \tilde{K}\left(A_{i}, B_{i}\right)}=\frac{1-u \alpha}{1-u}
$$

which implies the optimal choice of $\tilde{K}$. In the following, $K$ without tilde denotes the optimally chosen $\tilde{K}$. It is straightforward to show that $K_{u}=\frac{\partial K}{\partial u}<0$ and $K_{\alpha}=\frac{\partial K}{\partial \alpha}>0 . \alpha=1$ implies undistorted investment.

Firm 1 is assumed to have a high firm-specific profitability $A_{1}$ and a low location-specific profitability $B_{1}$. Firm 2 has a low $A_{2}$ and a high $B_{2}$. Roughly speaking, firm 1 is internationally mobile and firm 2 is not. Mobility means, that firm 1 leaves the country if its after-tax profits $\pi$ are smaller than the profits which could be earned abroad $\pi^{*}$.

The government maximizes the utility of the households according to the social welfare function

$$
W=U(c)+H(g)
$$

where $c$ is private consumption and $g$ is a publicly supplied good. Consumption $c$ is the after-tax income of the two firms. $g$ is financed by the tax revenues.

The government has the choice between two general strategies. The first is to levy high taxes, accepting that firm 1 will leave the country. In this case, the standard result of the taxation of locally fixed profits is valid: Investment is undistorted and the tax rate can reach $100 \%$.

The second is to choose the optimal tax policy subject to the constraint that firm 1 stays in the home market. In the following we will focus on this case. The maximization problem is:

$$
W=U\left(\sum\left(F_{i}(1-u)-(1-\alpha u) K_{i}\right)\right)+H\left(u \sum\left(F_{i}-\alpha K_{i}\right)\right)
$$

\footnotetext{
${ }^{8}$ Any other taxes than source taxes are ruled out.
} 
where $F_{i}$ denotes $F\left(K_{i}, A_{i}, B_{i}\right)$, subject to

$$
F_{1}(1-u)-(1-\alpha u) K_{1} \geq \pi^{*}
$$

The optimality conditions are:

$$
\begin{aligned}
W_{u}=0= & \left(H^{\prime}-U^{\prime}\right) \sum\left(F_{i}-\alpha K_{i}\right)+H^{\prime}\left(u \sum\left(F_{K_{i}}-\alpha\right) K_{i u}\right) \\
& +\lambda\left[\left(F_{1}-\alpha K_{1}\right)\right] \\
W_{\alpha}=0= & \left(H^{\prime}-U^{\prime}\right) \sum\left(u K_{i}\right)+H^{\prime}\left(u \sum\left(F_{K_{i}}-\alpha\right) K_{i \alpha}\right)+\lambda\left[-u K_{1}\right] \\
W_{\lambda}= & 0=\left(F_{1}(1-u)-(1-\alpha u) K_{1}\right)(1-u)-\pi^{*}
\end{aligned}
$$

where $\lambda$ is the Lagrangian shadow price. Note that with immobile firms the optimality conditions are the same with $\lambda=0$. In this case, the public good provision is efficient $\left(H^{\prime}=U^{\prime}\right)$ and investment is undistorted $(\alpha=1)$.

With $\lambda>0$, it follows from (6) and (7) that the closed economy result $H^{\prime}=U^{\prime}$, $\alpha=1, u>0$ cannot be an optimum anymore. Therefore try the solution with undistorted investment but underprovision of the public good $\left(H^{\prime}>U^{\prime}, \alpha=1\right.$, $u>0)$.

Given that $W_{u}=0$ is satisfied, it follows from equation (6) that:

$$
\lambda=-\frac{\left(H^{\prime}-U^{\prime}\right) \sum\left(F_{i}-K_{i}\right)}{\left(F_{1}-K_{1}\right)}
$$

Now replace $\lambda$ in (7) and rearrange.

$$
W_{\alpha}=\Omega\left[\frac{\sum\left(F_{i}-K_{i}\right)}{\sum K_{i}}-\frac{F_{1}-K_{1}}{K_{1}}\right]
$$

with $\Omega=\left(H^{\prime}-U^{\prime}\right) \frac{K_{1} \sum\left(u K_{i}\right)}{\left(F_{1}-K_{1}\right)}>0$. The welfare effect of varying $\alpha$, evaluated at $\alpha=1$, depends on whether the term in square brackets is positive or negative. To get the intuition, interpret the first term in the square brackets as the average return per unit of capital in the overall economy and the second term as the return per capital unit of firm 1 . That means, that $\alpha=1$ is an optimal strategy if the mobile firm is as profitable as the immobile one.

However, if one assumes that the mobile firm is more profitable than the rest 
of the economy, as does Bond (2000), the term in square brackets as well as the whole RHS of equation (10) becomes negative. A reduction in the tax allowance $\alpha$, i.e. a broadening of the tax base, leads to a rise in welfare.

How can a distortion of investment lead to increasing welfare? By broadening the tax base and lowering the tax rate the government redistributes tax liabilities from the high profits firm to the low profits firm. The government can thus increase overall tax revenues without losing the mobile firm. In other words, the government equalizes the marginal loss resulting from the investment distortion and the marginal gain resulting from additional tax revenues.

The opposite case is possible, too. Assume that the immobile firm is more profitable than the mobile firm. In this case, the government wants to redistribute tax liabilities from the less profitable firm to the more profitable one. It can do so by lowering the tax base and increasing the tax rate, i.e. by subsidizing investment. Such a tax system hits the profitable firms harder than the non-profitable ones.

The two firm model can be questioned concerning two aspects. First, under more realistic assumptions, it will probably not be optimal for the government to keep all firms in the home market. It will rather accept some exits and weigh the resulting losses in tax revenue against the gains of the remaining firms due to a less distorting tax system. Second, by distorting the tax system the government might drive out firms which are immobile and just break even under an undistorted tax system.

We therefore consider a more general model with a continuum of firms.

\section{A more general model}

\subsection{Firms}

Consider an economy with a continuum of mobile profit-maximizing firms, which differ in profitability. $A$ and $B$ are now independently distributed parameters with $A \subset\left\{A^{-}, A^{+}\right\}$and $B \subset\left\{B^{-}, B^{+}\right\}$, where $A^{-}$and $B^{-}$can be negative.

The firm decides not to produce if

$$
\pi(A, B)<0
$$


Let $A^{l}$ denote the vector of firm specific profitabilities for which $\pi\left(A^{l}, B\right)=0$, for a given $B$. In addition, firms can decide to change the production location and go abroad. In this case, firms have to bear the migration $\operatorname{cost} C$ which is equal across firms. Without loss of generality, we normalize location-specific profitability abroad to zero. Suppose that the foreign government sets its tax rate to $t$ and the rate of depreciation allowances to $\beta$. The firm stays in the home country if

$$
\pi(u, \alpha) \geq \pi^{*}(t, \beta)-C
$$

where the asterisk denotes the foreign country and. $A^{h}$ denotes the vector of firm specific profitabilities which satisfy $\pi=\pi^{*}-C$.

\subsection{Households}

Domestic households own all firms in the economy. Profits are their only source of income. Household consumption is therefore:

$$
c=\int_{B^{-}}^{B^{+}} \int_{A^{l}}^{A^{h}}[\pi] d A d B+\int_{B^{-}}^{B^{+}} \int_{A^{h}}^{A^{+}}\left[\pi^{*}-C\right] d A d B
$$

with

$$
\begin{aligned}
\pi & =F(K, A, B)(1-u)-(1-\alpha u) K \\
\pi^{*} & =F\left(K^{*}, A, B\right)(1-t)-(1-\beta t) K^{*}
\end{aligned}
$$

\subsection{Government}

The government uses profit tax revenue to finance the public good $g$. The budget constraint of the government is given by

$$
g=\int_{B^{-}}^{B^{+}} \int_{A^{l}}^{A^{h}} u(F(K, A, B)-\alpha K) d A d B
$$

The government is supposed to maximize the social welfare function $W$ :

$$
W=U(c)+H(g)
$$


As a benchmark case, consider first the optimal tax policy with respect to the tax rate and the tax base when firms are immobile.

\subsection{Optimal tax policy with immobile firms}

With $A^{h}>A^{+}$, the welfare function becomes

$W=U\left(\int_{B^{-}}^{B^{+}} \int_{A^{l}}^{A^{+}}[F(1-u)-(1-\alpha u) K] d A d B\right)+H\left(\int_{B^{-}}^{B^{+}} \int_{A^{l}}^{A^{+}} u(F-\alpha K) d A d B\right)$

with $F=F(K, A, B)$ for simplicity, subject to

$$
F\left(K, A^{l}\right)(1-u)-(1-\alpha u) K=0
$$

for every given level of $B$. Figure 1 shows the two-dimensional profitability space of the firms in the economy:

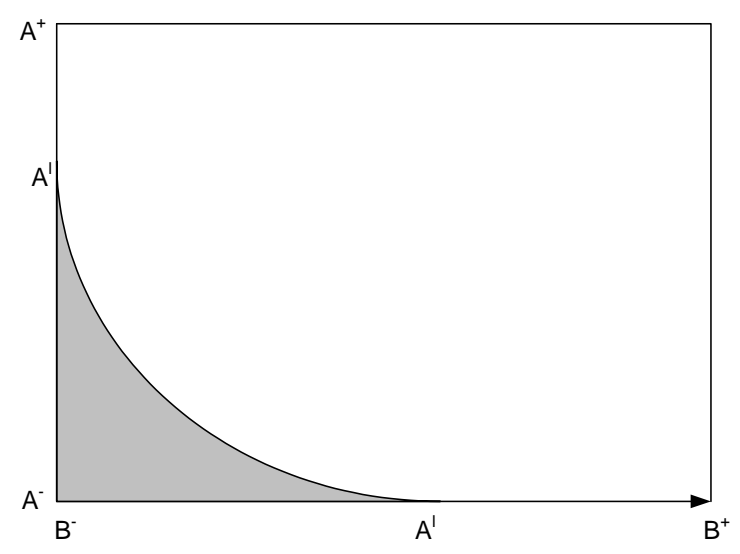

Figure 1: Immobile firms.

The firms in the shaded left bottom corner are not profitable enough and do not produce. Firms in the white area do produce and can be taxed. Firms along the $A^{l}$ frontier are indifferent between producing and leaving the market. By increasing (lowering) the effective tax burden, the government shifts the $A^{l}$ frontier to the lower left (upper right).

The optimality conditions with respect to $u$ and $\alpha$ are: 


$$
\begin{aligned}
\frac{\partial W}{\partial u}= & 0=\left(H^{\prime}-U^{\prime}\right) \int_{B^{-}}^{B^{+}} \int_{A^{l}}^{A^{+}}[(F-\alpha K)] d A d B \\
& \left.+H^{\prime} \int_{B^{-}}^{B^{+}} \int_{A^{l}}^{A^{+}}\left[u\left(F_{K}-\alpha\right) K_{u}\right] d A d B-H^{\prime} \int_{B^{-}}^{B^{+}}\left(u\left(F^{l}-\alpha K^{l}\right) \frac{\partial A^{l}}{\partial u}\right) d B 20\right) \\
\frac{\partial W}{\partial \alpha}= & 0=-\left(H^{\prime}-U^{\prime}\right) \int_{B^{-}}^{B^{+}} \int_{A^{l}}^{A^{+}}[u K] d A d B+H^{\prime} \int_{B^{-}}^{B^{+}} \int_{A^{l}}^{A^{+}}\left[u\left(F_{K}-\alpha\right) K_{\alpha}\right] d A d B \\
& -H^{\prime} \int_{B^{-}}^{B^{+}}\left(u\left(F^{l}-\alpha K^{l}\right) \frac{\partial A^{l}}{\partial \alpha}\right) d B
\end{aligned}
$$

The solution is the well-known result, that investment should not be distorted: $\alpha=1$, knowing that in this case it is $F_{K}-\alpha=0$ and $F^{l}-\alpha K^{l}=0$. The government sets the tax rate so that the marginal utility of the public good equals the marginal utility of private consumption: $H^{\prime}=U^{\prime}$ (Samuelson condition).

\subsection{Optimal tax policy with mobile firms}

Now assume that $A^{l}<A^{h}<A^{+}$, i.e. there are some firms which will produce abroad. In this case, the equilibrium can be illustrated as in figure 2 :

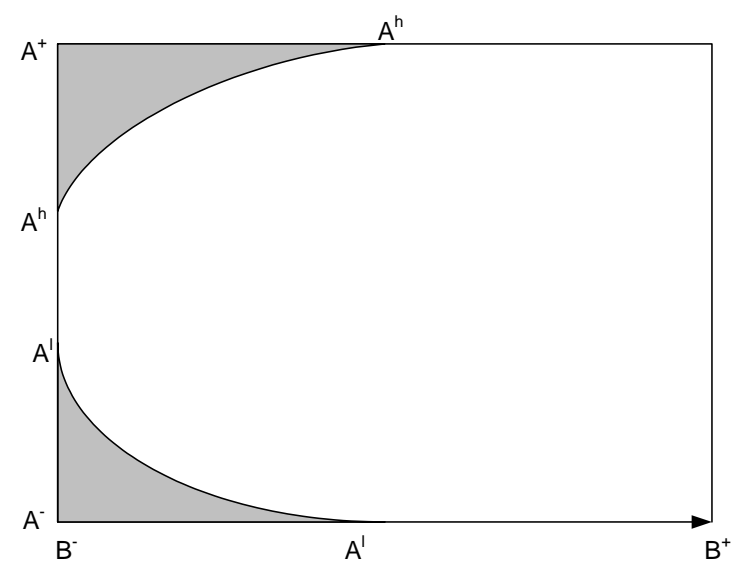

Figure 2: Mobile firms.

In addition to the firms which are not profitable enough to produce at all (bottom left), there are now firms which prefer producing abroad (top left). Only firms in the non-shaded area produce domestically an can be taxed by the domestic 
government. The government now maximizes the welfare function:

$W=U\left(\int_{B^{-}}^{B^{+}}\left[\int_{A^{l}}^{A^{h}} \pi d A+\int_{A^{h}}^{A^{+}}\left(\pi^{*}-C\right) d A\right] d B\right)+H\left(\int_{B^{-}}^{B^{+}} \int_{A^{l}}^{A^{h}} u(F-\alpha K) d A d B\right)$

with $\pi$ and $\pi^{*}$ defined as in (14) and (15), subject to

$$
\begin{aligned}
F\left(K, A^{l}\right)(1-u)-(1-\alpha u) K & =0 \\
F\left(K, A^{h}\right)(1-u)-(1-\alpha u) K & =F\left(K^{*}, A^{h}\right)(1-t)-(1-\beta t) K^{*}-C(24)
\end{aligned}
$$

The optimality condition with respect to $u$ is:

$$
\begin{aligned}
\frac{\partial W}{\partial u}= & 0=\left(H^{\prime}-U^{\prime}\right) \int_{B^{-}}^{B^{+}} \int_{A^{l}}^{A^{h}}[(F-\alpha K)] d A d B+H^{\prime} \int_{B^{-}}^{B^{+}} \int_{A^{l}}^{A^{h}}\left[u\left(F_{K}-\alpha\right) K_{u}\right] d A d B \\
& +H^{\prime} \int_{B^{-}}^{B^{+}}\left(u\left(F^{h}-\alpha K^{h}\right) \frac{\partial A^{h}}{\partial u}\right) d B-H^{\prime} \int_{B^{-}}^{B^{+}}\left(u\left(F^{l}-\alpha K^{l}\right) \frac{\partial A^{l}}{\partial u}\right) d B
\end{aligned}
$$

The optimality condition with respect to $\alpha$ is:

$$
\begin{aligned}
\frac{\partial W}{\partial \alpha}= & 0=-\left(H^{\prime}-U^{\prime}\right) \int_{B^{-}}^{B^{+}} \int_{A^{l}}^{A^{h}}[u K] d A d B+H^{\prime} \int_{B^{-}}^{B^{+}} \int_{A^{l}}^{A^{h}}\left[u\left(F_{K}-\alpha\right) K_{\alpha}\right] d A d B \\
& +\int_{B^{-}}^{B^{+}} H^{\prime}\left(u\left(F^{h}-\alpha K^{h}\right) \frac{\partial A^{h}}{\partial \alpha}\right) d B-\int_{B^{-}}^{B^{+}} H^{\prime}\left(u\left(F^{l}-\alpha K^{l}\right) \frac{\partial A^{l}}{\partial \alpha}\right) d B(26)
\end{aligned}
$$

First, it follows from equation (25) that $u>0, \alpha=1, H^{\prime}=U^{\prime}$ cannot be an optimum, because

$$
\frac{\partial W}{\partial u}=\int_{B^{-}}^{B^{+}} H^{\prime}\left(u\left(F\left(A, K^{h}\right)-K^{h}\right) \frac{\partial A^{h}}{\partial u}\right) d B \neq 0
$$

Second, $u$ has to be greater than zero to satisfy $\frac{\partial W}{\partial u}=0$. This can be explained as follows: The first term on the RHS of equation (25) is strictly positive, the three other terms are strictly negative. Therefore, $u=0$ and $u<0$ are no possible solutions.

Can $u>0, \alpha=1, H^{\prime}>U^{\prime}$ be an optimum? 


$$
\begin{aligned}
\frac{\partial W}{\partial u}= & 0=\left(H^{\prime}-U^{\prime}\right) \int_{B^{-}}^{B^{+}} \int_{A^{l}}^{A^{l}}[(F-K)] d A d B \\
& +H^{\prime} \int_{B^{-}}^{B^{+}}\left(u\left(F^{h}-K^{h}\right) \frac{\partial A^{h}}{\partial u}\right) d B \\
\frac{\partial W}{\partial \alpha}= & 0=-\left(H^{\prime}-U^{\prime}\right) \int_{B^{-}}^{B^{+}} \int_{A^{l}}^{A^{l}}[u K] d A d B \\
& +H^{\prime} \int_{B^{-}}^{B^{+}}\left(u\left(F^{h}-K^{h}\right) \frac{\partial A^{h}}{\partial \alpha}\right) d B
\end{aligned}
$$

As demonstrated in the appendix, given $\frac{\partial W}{\partial u}=0$, it follows that

$$
\frac{\partial W}{\partial \alpha}=\Omega\left(\bar{r}-r^{h}-\frac{\operatorname{cov}\left[\left(F^{h}-K^{h}\right) \frac{d A^{h}}{d \alpha}, \frac{F^{h}-K^{h}}{K^{h}}\right]}{\overline{\left(F^{h}-K^{h}\right) \frac{d A^{h}}{d \alpha}}}\right)
$$

where $\bar{r}=\frac{\overline{F-K}}{\bar{K}}$ is the average return per capital unit of all firms operating domestically and $r^{h}=\overline{\left(\frac{F^{h}-K^{h}}{K^{h}}\right)}$ is the average return per capital unit of the firms who are just indifferent between staying and leaving.

$$
\Omega=\left(H^{\prime}-U^{\prime}\right) \frac{\int_{B^{-}}^{B^{+}} u\left(F\left(A, K^{h}\right)-K^{h}\right) \frac{\partial A^{h}}{\partial \alpha} d B}{\int_{B^{-}}^{B^{+}}\left(u\left(F^{h}-K^{h}\right) \frac{d A^{h}}{d \alpha} \frac{F^{h}-K^{h}}{u K^{h}}\right) d B} \int_{B^{-}}^{B^{+}} \int_{A^{l}}^{A^{h}} u K d A d B>0
$$

is some scale factor.

How can (30) be interpreted? First, if the covariance term is equal to zero, (30) does not differ qualitatively from the result in the simple two firm economy. Define the marginal group of firms as those firms which are just indifferent between staying and leaving the country. If the average marginal firm is more profitable than the average non-marginal firm in the economy, the optimal tax policy is to set $\alpha<1$ (tax rate cut cum base broadening). If the two groups do not differ in average profitability, the tax system should not distort investment $(\alpha=1)$. If the average marginal firm is less profitable, the tax system should subsidize investment $(\alpha>1)$. 
Second, the covariance measures the correlation between the profitability $\left(\frac{F^{h}-K^{h}}{K^{h}}\right)$ and the elasticity of the marginal firms with respect to $\alpha$, weighted by the tax base $\left(\left(F^{h}-K^{h}\right) \frac{d A^{h}}{d \alpha}\right)$. To get the intuition, consider the following example: Assume that profitability increases in $B$. Assume further that the response of the $A^{h}$-firms rises with $B$ as well. In this case, the covariance term is positive. That means that, even if the average marginal firm profitability is equal to the average overall firm profitability, the optimal strategy is a tax base with $\alpha<1$. The reason is that among the marginal firms the highly profitable firms react more elastically to tax base changes.

\section{Discussion and concluding remarks}

The analysis in the preceding section has shown that, under simple assumptions on firm mobility, the efficiency property of undistorted investment in the optimal tax system vanishes. How do our results relate to the literature, and what policy implications do they have?

First, our results question the standard result that a consumption tax system is desirable when capital is internationally mobile. The mobility of firms is a plausible assumption and plays an important role in policy debates around the world. Our model shows that a consumption tax which leaves the marginal investment untaxed is the optimal policy response only in the special case where the marginal firm (which is indifferent between staying and moving) is exactly as profitable as the rest of the economy.

Second, our model can be understood as part of the literature that explains observable inefficiencies in tax systems by the lack of appropriate instruments. In the presence of internationally mobile firms the government would like to discriminate between mobile and immobile firms. In this model we assumed that the government faces informational or political constraints and has no means to do so.

Note that relaxing the assumption that the tax rate has to be equal for every firm in the economy would allow for discrimination of firms according to their mobility. It is straightforward to show that the optimal tax policy (i.e. maximization of social surplus) would imply investment neutrality. The government would then set individual tax rates for each firm such that each firm with a mobility above a 
certain threshold is indifferent between staying and moving, i.e. for each of these firms equation (24) holds.

In a setting where the government lacks the appropriate instruments for perfect discrimination, a tax rate cut cum base broadening strategy can be optimal. Other examples of this literature are the paper by Haufler \& Schjelderup (2000) and Fuest \& Hemmelgarn (2005), as discussed in the introductory section. Osmundsen, Hagen \& Schjelderup (1998) describe a world in which the government cannot observe mobility of firms but can offer two different tax contracts. They show that mobile firms will choose the type of taxation that distorts marginal investment. The distortionary tax system is accepted in order to overcome information problems. Hong \& Smart (2005) show that tax havens can be efficiency enhancing because they allow mobile firms to lower their effective tax rate without leaving the country in which they produce.

Third, of course, our results depend on strict assumptions as does every stylized model. It would be interesting to see if our results hold if firm mobility is allowed to interact with the opportunity of profit shifting via transfer pricing or thin capitalization, or with foreign firm ownership. Furthermore, we could ask what happens when governments have other tax instruments like wage taxes, sales taxes and so on. In reality, the present value of depreciation allowances and the cost of capital differ per capital asset; it is tempting to ask how this observation fits to our results. We leave this to further research.

We may conclude that the optimal strategy when firms are internationally mobile can be taxation, subsidization or non-distortion of the marginal investment. The results depend crucially on the profitability of the mobile firms relative to the average of the overall economy. In any case, the tax burden is redistributed from the mobile to the immobile firms. Our results may contribute to understanding recent tax policy developments in many OECD countries. Both the tax rate cut cum base broadening strategy as well as the subsidization of the marginal investment can be interpreted as optimal policy responses to growing firm mobility. 


\section{Appendix}

This appendix shows how to derive equation (30). First, recall equations (23) and (24). Given the level of $B$, how do $u$ and $\alpha$ affect $A^{h}$ ?

$$
\begin{aligned}
\left.\frac{d A^{h}}{d u}\right|_{B=\text { const }} & =\frac{F\left(A^{h}, K^{h}\right)-\alpha K^{h}}{F_{A}\left(A^{h}, K^{h}\right)(1-u)-F_{A}\left(A^{h}, K^{h *}\right)(1-t)}<0 \\
\left.\frac{d A^{h}}{d \alpha}\right|_{B=\text { const }} & =\frac{-u K^{h}}{F_{A^{h}}\left(A^{h}, K^{h}\right)(1-u)-F_{A^{h}}\left(A^{h}, K^{h *}\right)(1-t)}>0
\end{aligned}
$$

Note that

$$
\frac{d A^{h}}{d \alpha}=-\frac{d A^{h}}{d u}\left(\frac{u K^{h}}{F\left(A^{h}, K^{h}\right)-\alpha K^{h}}\right)
$$

Given the level of $B$, how do $u$ and $\alpha$ affect $A^{l}$ ?

$$
\begin{aligned}
\left.\frac{d A^{l}}{d u}\right|_{B=\text { const }} & =\frac{F\left(A^{l}, K^{l}\right)-\alpha K^{l}}{F_{A^{l}}\left(A^{l}, K^{l}\right)(1-u)}>0 \\
\left.\frac{d A^{l}}{d \alpha}\right|_{B=\text { const }} & =\frac{-u K^{l}}{F_{A^{l}}\left(A^{l}, K^{l}\right)(1-u)}<0
\end{aligned}
$$

With (32) it follows for equation (28):

$$
\frac{\partial W}{\partial u}=\left(H^{\prime}-U^{\prime}\right) \int_{B^{-}}^{B^{+}} \int_{A^{l}}^{A^{h}}(F-K) d A d B-H^{\prime} \int_{B^{-}}^{B^{+}}\left(u\left(F^{h}-K^{h}\right) \frac{d A^{h}}{d \alpha} \frac{F^{h}-K^{h}}{u K^{h}}\right) d B=0
$$

Solve for $H^{\prime}=\frac{\left(H^{\prime}-U^{\prime}\right) \int_{B^{-}}^{B^{+}} \int_{A^{l}}^{A^{h}}[(F-K)] d A d B}{\int_{B^{-}}^{B^{+}}\left(u\left(F^{h}-K^{h}\right) \frac{d A^{h}}{d \alpha} \frac{F^{h}-K^{h}}{u K^{h}}\right) d B}$ and replace $H^{\prime}$ in equation (29):

$$
\begin{aligned}
\frac{\partial W}{\partial \alpha}= & -\left(H^{\prime}-U^{\prime}\right) \int_{B^{-}}^{B^{+}} \int_{A^{l}}^{A^{h}} u K d A d B \\
& +\frac{\left(H^{\prime}-U^{\prime}\right) \int_{B^{-}}^{B^{+}} \int_{A^{l}}^{A^{h}}[(F-K)] d A d B}{\int_{B^{-}}^{B^{+}}\left(u\left(F^{h}-K^{h}\right) \frac{d A^{h}}{d \alpha} \frac{F^{h}-K^{h}}{u K^{h}}\right) d B} \int_{B^{-}}^{B^{+}} u\left(F^{h}-K^{h}\right) \frac{\partial A^{h}}{\partial \alpha} d B
\end{aligned}
$$

Rearrange and write: 


$$
\begin{aligned}
\frac{\partial W}{\partial \alpha}= & \left(H^{\prime}-U^{\prime}\right) \frac{\int_{B^{-}}^{B^{+}}\left(F^{h}-K^{h}\right) \frac{\partial A^{h}}{\partial \alpha} d B}{\int_{B^{-}}^{B^{+}}\left(\left(F^{h}-K^{h}\right) \frac{d A^{h}}{d \alpha} \frac{F^{h}-K^{h}}{K^{h}}\right) d B} \int_{B^{-}}^{B^{+}} \int_{A^{l}}^{A^{h}} K d A d B \\
& {\left[\frac{\int_{B^{-}}^{B^{+}} \int_{A^{l}}^{A^{h}}[(F-K)] d A d B}{\int_{B^{+}}^{B^{+}} \int_{A^{l}}^{A^{h}} K d A d B}-\frac{\int_{B^{-}}^{B^{+}}\left(\left(F^{h}-K^{h}\right) \frac{d A^{h}}{d \alpha} \frac{F^{h}-K^{h}}{K^{h}}\right) d B}{\int_{B^{-}}^{B^{+}}\left(F^{h}-K^{h}\right) \frac{\partial A^{h}}{\partial \alpha} d B}\right] }
\end{aligned}
$$

Now consider the second term in the square brackets. It is:

$$
\begin{aligned}
& \operatorname{cov}\left[\left(F^{h}-K^{h}\right) \frac{d A^{h}}{d \alpha}, \frac{F^{h}-K^{h}}{K^{h}}\right] \\
= & \int_{B^{-}}^{B^{+}}\left(\left(F^{h}-K^{h}\right) \frac{d A^{h}}{d \alpha} \frac{F^{h}-K^{h}}{K^{h}}\right) d B-\int_{B^{-}}^{B^{+}}\left(\left(F^{h}-K^{h}\right) \frac{d A^{h}}{d \alpha}\right) d B \cdot \int_{B^{-}}^{B^{+}}\left(\frac{F^{h}-K^{h}}{K^{h}}\right) d B
\end{aligned}
$$

Rearrange:

$$
\frac{\int_{B^{-}}^{B^{+}}\left(\left(F^{h}-K^{h}\right) \frac{d A^{h}}{d \alpha} \frac{F^{h}-K^{h}}{K^{h}}\right) d B}{\int_{B^{-}}^{B^{+}}\left(F^{h}-K^{h}\right) \frac{\partial A^{h}}{\partial \alpha} d B}=\frac{\operatorname{cov}\left[\left(F^{h}-K^{h}\right) \frac{d A^{h}}{d \alpha}, \frac{F^{h}-K^{h}}{K^{h}}\right]}{\int_{B^{-}}^{B^{+}}\left(\left(F^{h}-K^{h}\right) \frac{d A^{h}}{d \alpha}\right) d B}+\int_{B^{-}}^{B^{+}}\left(\frac{F^{h}-K^{h}}{K^{h}}\right) d B
$$

where the LHS is the second term is square brackets of equation (33). Now rewrite equation (33):

$$
\frac{\partial W}{\partial \alpha}=\Omega\left(\bar{r}-r^{h}-\frac{\operatorname{cov}\left[\left(F^{h}-K^{h}\right) \frac{d A^{h}}{d \alpha}, \frac{F^{h}-K^{h}}{K^{h}}\right]}{\left(F^{h}-K^{h}\right) \frac{d A^{h}}{d \alpha}}\right)
$$

with $\bar{r}=\frac{\overline{F-K}}{\bar{K}}$ the average return per capital unit, $r^{h}=\overline{\left(\frac{F^{h}-K^{h}}{K^{h}}\right)}$ the return per capital unit of the most productive firm and

$$
\Omega=\left(H^{\prime}-U^{\prime}\right) \frac{\int_{B^{-}}^{B^{+}} u\left(F\left(A, K^{h}\right)-K^{h}\right) \frac{\partial A^{h}}{\partial \alpha} d B}{\int_{B^{-}}^{B^{+}}\left(u\left(F^{h}-K^{h}\right) \frac{d A^{h}}{d \alpha} \frac{F^{h}-K^{h}}{u K^{h}}\right) d B} \int_{B^{-}}^{B^{+}} \int_{A^{l}}^{A^{h}} u K d A d B>0
$$

some scale factor. 


\section{References}

Becker, J. \& Fuest, C. (2005). Does Germany collect revenue from taxing capital income?, CESifo Working Paper No. 1489.

Boadway, R., Cuff, K. \& Marceau, N. (2002). Inter-jurisdictional competition for firms, International Economic Review 43: 761-82.

Bond, S. R. (2000). Levelling Up or Levelling Down? Some Reflections on the ACE and CBIT Proposals, and the Future of the Corporate Tax Base, in S. Cnossen (ed.), Taxing Capital Income in the European Union. Issues and Options for Reform, Oxford University Press, pp. 161-179.

Devereux, M. P., Griffith, R. \& Klemm, A. (2002). Corporate income tax reforms and international tax competition, Economic policy 17(2): 450-493.

Devereux, M. P., Lockwood, B. \& Redoano, M. (2004). Do countries compete over corporate tax rates? University of Warwick, Working Paper.

Fuest, C. (2005). Economic integration and tax policy with endogenous foreign firm ownership, Journal of Public Economics 89: 1823-1840.

Fuest, C. \& Hemmelgarn, T. (2005). Corporate tax policy, foreign firm ownership and thin capitalization, Regional Science and Urban Economics 35: 508-526.

Gordon, R. H. (1986). Taxation of Investment and Savings in the World Economy, American Economic Review 76: 1086-1102.

Gordon, R. H. (1992). Can capital income taxes survive in open economies?, Journal of Finance pp. 1159-1180.

Gordon, R. H., Kalambokidis, L., Rohaly, J. \& Slemrod, J. (2004). Toward a consumption tax, and beyond, American Economic Review, Papers and Proceedings 94(2): 161-165.

Haufler, A. \& Schjelderup, G. (2000). Corporate tax systems and cross country profit shifting, Oxford Economic Papers 52: 306-325. 
Hong, Q. \& Smart, M. (2005). In praise of tax havens: International tax planning and foreign direct investment. Unpublished manuscript, University of Toronto.

Lipsey, R. E. (2001). Foreign direct investment and the operations of multinational firms: comcepts, history and data. NBER Working Paper No. 8665.

Osmundsen, P., Hagen, K. P. \& Schjelderup, G. (1998). Internationally mobile firms and tax policy, Journal of International Economics 45: 97-113.

Ottaviano, G. I. P. \& Thisse, J.-F. (2003). Agglomeration and Economic Geograpy. CEPR Discussion Paper No. 3838.

Sinn, H. W. (1990). Tax Harmonization and Tax Competition in Europe, European Economic Review 34(2-3): 489-504.

Slemrod, J. (2004). Are corporate tax rates, or countries, converging?, Journal of Public Economics 88: 1169-1186.

Steinmo, S. (2003). The evolution of policy ideas: Tax policy in the 20th century, British Journal of Politics and International Relations 5: 206-236.

Swank, D. \& Steinmo, S. (2002). The new political economy of taxation in advanced capitalist democracies, American Journal of Political Science 46: 642655 .

Whalley, J. (1990). Foreign responses to US tax reform, in J. Slemrod (ed.), Do taxes matter? The impact of the Tax Reform Act of 1986, MIT Press, Cambridge and London, pp. 286-314. 


\title{
CESifo Working Paper Series
}

\author{
(for full list see www.cesifo-group.de)
}

1529 Giorgio Fazio, Ronald MacDonald and Jacques Mélitz, Trade Costs, Trade Balances and Current Accounts: An Application of Gravity to Multilateral Trade, August 2005

1530 Thomas Christiaans, Thomas Eichner and Ruediger Pethig, A Micro-Level 'Consumer Approach’ to Species Population Dynamics, August 2005

1531 Samuel Hanson, M. Hashem Pesaran and Til Schuermann, Firm Heterogeneity and Credit Risk Diversification, August 2005

1532 Mark Mink and Jakob de Haan, Has the Stability and Growth Pact Impeded Political Budget Cycles in the European Union?, September 2005

1533 Roberta Colavecchio, Declan Curran and Michael Funke, Drifting Together or Falling Apart? The Empirics of Regional Economic Growth in Post-Unification Germany, September 2005

1534 Kai A. Konrad and Stergios Skaperdas, Succession Rules and Leadership Rents, September 2005

1535 Robert Dur and Amihai Glazer, The Desire for Impact, September 2005

1536 Wolfgang Buchholz and Wolfgang Peters, Justifying the Lindahl Solution as an Outcome of Fair Cooperation, September 2005

1537 Pieter A. Gautier, Coen N. Teulings and Aico van Vuuren, On-the-Job Search and Sorting, September 2005

1538 Leif Danziger, Output Effects of Inflation with Fixed Price- and Quantity-Adjustment Costs, September 2005

1539 Gerhard Glomm, Juergen Jung, Changmin Lee and Chung Tran, Public Pensions and Capital Accumulation: The Case of Brazil, September 2005

1540 Yvonne Adema, Lex Meijdam and Harrie A. A. Verbon, The International Spillover Effects of Pension Reform, September 2005

1541 Richard Disney, Household Saving Rates and the Design of Social Security Programmes: Evidence from a Country Panel, September 2005

1542 David Dorn and Alfonso Sousa-Poza, Early Retirement: Free Choice or Forced Decision?, September 2005

1543 Clara Graziano and Annalisa Luporini, Ownership Concentration, Monitoring and Optimal Board Structure, September 2005 
1544 Panu Poutvaara, Social Security Incentives, Human Capital Investment and Mobility of Labor, September 2005

1545 Kjell Erik Lommerud, Frode Meland and Odd Rune Straume, Can Deunionization Lead to International Outsourcing?, September 2005

1546 Robert Inklaar, Richard Jong-A-Pin and Jakob de Haan, Trade and Business Cycle Synchronization in OECD Countries: A Re-examination, September 2005

1547 Randall K. Filer and Marjorie Honig, Endogenous Pensions and Retirement Behavior, September 2005

1548 M. Hashem Pesaran, Til Schuermann and Bjoern-Jakob Treutler, Global Business Cycles and Credit Risk, September 2005

1549 Ruediger Pethig, Nonlinear Production, Abatement, Pollution and Materials Balance Reconsidered, September 2005

1550 Antonis Adam and Thomas Moutos, Turkish Delight for Some, Cold Turkey for Others?: The Effects of the EU-Turkey Customs Union, September 2005

1551 Peter Birch Sørensen, Dual Income Taxation: Why and how?, September 2005

1552 Kurt R. Brekke, Robert Nuscheler and Odd Rune Straume, Gatekeeping in Health Care, September 2005

1553 Maarten Bosker, Steven Brakman, Harry Garretsen and Marc Schramm, Looking for Multiple Equilibria when Geography Matters: German City Growth and the WWII Shock, September 2005

1554 Paul W. J. de Bijl, Structural Separation and Access in Telecommunications Markets, September 2005

1555 Ueli Grob and Stefan C. Wolter, Demographic Change and Public Education Spending: A Conflict between Young and Old?, October 2005

1556 Alberto Alesina and Guido Tabellini, Why is Fiscal Policy often Procyclical?, October 2005

1557 Piotr Wdowinski, Financial Markets and Economic Growth in Poland: Simulations with an Econometric Model, October 2005

1558 Peter Egger, Mario Larch, Michael Pfaffermayr and Janette Walde, Small Sample Properties of Maximum Likelihood Versus Generalized Method of Moments Based Tests for Spatially Autocorrelated Errors, October 2005

1559 Marie-Laure Breuillé and Robert J. Gary-Bobo, Sharing Budgetary Austerity under Free Mobility and Asymmetric Information: An Optimal Regulation Approach to Fiscal Federalism, October 2005 
1560 Robert Dur and Amihai Glazer, Subsidizing Enjoyable Education, October 2005

1561 Carlo Altavilla and Paul De Grauwe, Non-Linearities in the Relation between the Exchange Rate and its Fundamentals, October 2005

1562 Josef Falkinger and Volker Grossmann, Distribution of Natural Resources, Entrepreneurship, and Economic Development: Growth Dynamics with Two Elites, October 2005

$1563 \mathrm{Yu}-\mathrm{Fu}$ Chen and Michael Funke, Product Market Competition, Investment and Employment-Abundant versus Job-Poor Growth: A Real Options Perspective, October 2005

1564 Kai A. Konrad and Dan Kovenock, Equilibrium and Efficiency in the Tug-of-War, October 2005

1565 Joerg Breitung and M. Hashem Pesaran, Unit Roots and Cointegration in Panels, October 2005

1566 Steven Brakman, Harry Garretsen and Marc Schramm, Putting New Economic Geography to the Test: Free-ness of Trade and Agglomeration in the EU Regions, October 2005

1567 Robert Haveman, Karen Holden, Barbara Wolfe and Andrei Romanov, Assessing the Maintenance of Savings Sufficiency Over the First Decade of Retirement, October 2005

1568 Hans Fehr and Christian Habermann, Risk Sharing and Efficiency Implications of Progressive Pension Arrangements, October 2005

1569 Jovan Žamac, Pension Design when Fertility Fluctuates: The Role of Capital Mobility and Education Financing, October 2005

1570 Piotr Wdowinski and Aneta Zglinska-Pietrzak, The Warsaw Stock Exchange Index WIG: Modelling and Forecasting, October 2005

1571 J. Ignacio Conde-Ruiz, Vincenzo Galasso and Paola Profeta, Early Retirement and Social Security: A Long Term Perspective, October 2005

1572 Johannes Binswanger, Risk Management of Pension Systems from the Perspective of Loss Aversion, October 2005

1573 Geir B. Asheim, Wolfgang Buchholz, John M. Hartwick, Tapan Mitra and Cees Withagen, Constant Savings Rates and Quasi-Arithmetic Population Growth under Exhaustible Resource Constraints, October 2005

1574 Christian Hagist, Norbert Klusen, Andreas Plate and Bernd Raffelhueschen, Social Health Insurance - the Major Driver of Unsustainable Fiscal Policy?, October 2005

1575 Roland Hodler and Kurt Schmidheiny, How Fiscal Decentralization Flattens Progressive Taxes, October 2005 
1576 George W. Evans, Seppo Honkapohja and Noah Williams, Generalized Stochastic Gradient Learning, October 2005

1577 Torben M. Andersen, Social Security and Longevity, October 2005

1578 Kai A. Konrad and Stergios Skaperdas, The Market for Protection and the Origin of the State, October 2005

1579 Jan K. Brueckner and Stuart S. Rosenthal, Gentrification and Neighborhood Housing Cycles: Will America’s Future Downtowns be Rich?, October 2005

1580 Elke J. Jahn and Wolfgang Ochel, Contracting Out Temporary Help Services in Germany, November 2005

1581 Astri Muren and Sten Nyberg, Young Liberals and Old Conservatives - Inequality, Mobility and Redistribution, November 2005

1582 Volker Nitsch, State Visits and International Trade, November 2005

1583 Alessandra Casella, Thomas Palfrey and Raymond Riezman, Minorities and Storable Votes, November 2005

1584 Sascha O. Becker, Introducing Time-to-Educate in a Job Search Model, November 2005

1585 Christos Kotsogiannis and Robert Schwager, On the Incentives to Experiment in Federations, November 2005

1586 Søren Bo Nielsen, Pascalis Raimondos-Møller and Guttorm Schjelderup, Centralized vs. De-centralized Multinationals and Taxes, November 2005

1587 Jan-Egbert Sturm and Barry Williams, What Determines Differences in Foreign Bank Efficiency? Australian Evidence, November 2005

1588 Steven Brakman and Charles van Marrewijk, Transfers, Non-Traded Goods, and Unemployment: An Analysis of the Keynes - Ohlin Debate, November 2005

1589 Kazuo Ogawa, Elmer Sterken and Ichiro Tokutsu, Bank Control and the Number of Bank Relations of Japanese Firms, November 2005

1590 Bruno Parigi and Loriana Pelizzon, Diversification and Ownership Concentration, November 2005

1591 Claude Crampes, Carole Haritchabalet and Bruno Jullien, Advertising, Competition and Entry in Media Industries, November 2005

1592 Johannes Becker and Clemens Fuest, Optimal Tax Policy when Firms are Internationally Mobile, November 2005 